\title{
Adsorption of DNA Oligonucleotides by Titanium Dioxide Nanoparticles
}

Xu Zhang ${ }^{\dagger, \ddagger}$, Feng Wang ${ }^{\dagger}$, Biwu Liu ${ }^{\dagger}$, Erin Y. Kelly ${ }^{\dagger}$, Mark R. Servos ${ }^{\ddagger}$ and Juewen Liu ${ }^{\dagger, *}$

† Department of Chemistry and Waterloo Institute for Nanotechnology, ${ }^{\circ}$ Department of Biology, University of Waterloo, 200 University Avenue West, Waterloo, Ontario, Canada N2L 3G1.

"To whom correspondence should be addressed: liujw@uwaterloo.ca

This document is the Accepted Manuscript version of a Published Work that appeared in final form in Langmuir, copyright $\odot$ A American Chemical Society after peer review and technical editing by publisher. To access the final edited and published work see http://dx.doi.org/10.1021/la404633p 


\begin{abstract}
Titanium dioxide $\left(\mathrm{TiO}_{2}\right)$ or titania shows great promise in detoxification and drug delivery. To reach its full potential, it is important to interface $\mathrm{TiO}_{2}$ with biomolecules to harness their molecular recognition function. To this end, DNA attachment is an important topic. Previous work has mainly focused on long double-stranded DNA or single nucleotides. For biosensor development and targeted drug delivery, it is more important to use single-stranded oligonucleotides. Herein, the interaction between fluorescently labeled oligonucleotides and $\mathrm{TiO}_{2}$ nanoparticles is reported. The point of zero charge (PZC) of $\mathrm{TiO}_{2}$ is around 6 in water or in acetate buffer, so they are positively charged at lower $\mathrm{pH}$. However, if in phosphate or citrate buffer, the particles are negatively charged even at $\mathrm{pH} \sim 2$, suggesting strong adsorption of buffer anions. DNA adsorption takes places mainly via the phosphate backbone although the bases might also have moderate contributions. Peptide nucleic acids (PNA) with an amide backbone cannot be adsorbed. DNA adsorption is strongly affected by inorganic anions, where phosphate and citrate can strongly inhibit DNA adsorption. DNA adsorption is also promoted by adding salt or lowering $\mathrm{pH}$. DNA adsorption is accompanied with fluorescence quenching and doublestranded DNA showed reduced quenching, allowing detection of DNA using $\mathrm{TiO}_{2}$ nanoparticles.
\end{abstract}




\section{Introduction}

Titanium dioxide $\left(\mathrm{TiO}_{2}\right)$ or titania is an important industrial material for a diverse range of applications, where it is best known as a white pigment. It is also used in sunscreens and food additives, suggesting its excellent biocompatibility. ${ }^{1-3}$ Indeed, a number of assays confirm that even relatively high concentrations (e.g. $0.2 \mathrm{mg} / \mathrm{mL}$ ) of titania do not show noticeable toxicity to cells and animals. ${ }^{4}$ This makes titania a useful vehicle for drug delivery. ${ }^{5}$ At the same time, $\mathrm{TiO}_{2}$ is a photocatalyst widely explored for water detoxification and disinfection under light exposure. ${ }^{6}$ Attaching affinity ligands to its surface can improve specificity to selectively kill cancer or bacterial cells. ${ }^{7}$

Compared to the vast amount of work on gold, carbon or silica nanoparticles (NPs), ${ }^{8-13}$ functionalization of titania with biomolecules is reported only in a few cases. For example, antibodies were physisorbed to target cancer cells. ${ }^{14,15}$ To achieve covalent attachment, Brook and co-workers used the sol-gel chemistry to graft a layer of amino-modified silane on titania, upon which biotin or protein was coupled. ${ }^{7,16,17}$ Levina et al considered that titania is negatively charge at neutral $\mathrm{pH}$. They prepared a DNA/polylysine conjugate, where the positively charged polylysine is used to anchor on titania surface and the DNA fragment can hybridize to its complementary strand. ${ }^{18,19}$

To make the attachment chemistry more cost-effective, it is desirable to directly adsorb nonmodified DNA. Zhu et al studied the adsorption of calf thymus DNA by $\mathrm{TiO}_{2} \mathrm{NPs}$ and they concluded that phosphate is responsible for DNA adsorption based on IR spectroscopy. ${ }^{20}$ Suzuki et al used sonication to assist the adsorption of salmon testes DNA, which is also a long ds-DNA. ${ }^{21}$ They found that the DNA adsorbed very tightly and did not desorb even by heating at $56{ }^{\circ} \mathrm{C}$ for several hours. Desorption occurred only at $98{ }^{\circ} \mathrm{C}$ in $\mathrm{pH} 14$ solution. In addition to the previously proposed phosphate binding, the author suspected that adsorption might also take place by electrostatic interaction at acidic $\mathrm{pH}$ (where the surface of $\mathrm{TiO}_{2}$ is positively charged) or by bridging cations. This adsorption reaction was used to precipitate $\mathrm{TiO}_{2}$ NPs for environmental remediation. ${ }^{22}$ The authors further increased DNA 
loading capacity by lowering the buffer $\mathrm{pH}$ to 2 , which was attributed to the reduced electrostatic repulsion between DNA and the particle surface. ${ }^{23}$ Cleaves et al studied the adsorption of several DNA/RNA bases, nucleosides and monophosphate nucleotides, where they concluded that nucleotides adsorbed more tightly than nucleobases. ${ }^{24}$ They further noticed that cytosine was adsorbed significantly more at lower $\mathrm{pH}$, while adenine and uracil was less affected. So far, it is not conclusive whether DNA adsorption to titania is achieved via the bases or the phosphate backbone.

All the previous work suggested that both long ds-DNA and single nucleobases/nucleotides can be adsorbed by $\mathrm{TiO}_{2}$ NPs. For analytical and biomedical applications, it is more desirable to attach ssDNA oligonucleotides with well-defined sequences such as aptamers. ${ }^{8-13,25}$ Using oligonucleotide probes also allows systematic studies on the effect of DNA sequence and length. We previously employed oligonucleotide probes to study their interaction with gold, ${ }^{26,27}$ graphene oxide, ${ }^{28}$ coordination polymers, ${ }^{29}$ and nanoceria. ${ }^{30}$ In this paper, we report the surface interaction of short ssDNA on $\mathrm{TiO}_{2}$ NPs.

\section{Materials and Methods}

Chemicals. All of the DNA samples were purchased from Integrated DNA Technologies (IDT, Coralville, IA) and were purified by standard desalting. The peptide nucleic acid (PNA) sample was purchased from Biosynthesis Inc. (Lewisville, TX) and the stock was dissolved in $0.1 \%$ trifluoroacetic acid. The sequences of DNA used in this work are shown in Table 1. $\mathrm{TiO}_{2} \mathrm{NPs}$ (catalog number: 718467) were purchased from Sigma-Aldrich. Sodium phosphate, sodium citrate, 4-(2-hydroxyethyl)1-piperazineethanesulfonic acid (HEPES), sodium acetate, sodium nitrate, and all the ribonucleosides were from Mandel Scientific (Guelph, Ontario, Canada). Milli-Q water was used for all the experiments. 
Table 1: DNA and PNA used in this work.

\begin{tabular}{|c|c|}
\hline DNA name & Sequence $\left(5^{\prime}\right.$ to $\left.3^{\prime}\right)$ and modification \\
\hline FAM-DNA1 & FAM-TTCTTTCTTCCCCTTGTTTGTT \\
\hline cDNA1 & AACAAACAAGGGGAAGAAAGAA \\
\hline $\mathrm{T}_{15}$ & TTTTTTTTTTTTTTT \\
\hline FAM- $\mathrm{A}_{15}$ & FAM-AAAAAAAAAAAAAAA \\
\hline FAM-C 15 & FAM-CCCCCCCCCCCCCCC \\
\hline FAM-G 15 & FAM-GGGGGGGGGGGGGGG \\
\hline $\mathrm{FAM}_{-15}$ & FAM-TTTTTTTTTTTTTTT \\
\hline FAM-A 30 & FAM- AAAAAAAAAAAAAAAAAAAAAAAAAAAAAA \\
\hline \multirow[t]{2}{*}{ FAM-A 45} & FAM-AAAAAAAAAAAAAAAAAAAAAAAAAAAAAA AAAAAAA \\
\hline & AAAAAAAA \\
\hline Cy3-T 15 & Су3-ТTTTTTTTTTTTTTТ \\
\hline PNA & FAM-CACTGACCTGGG \\
\hline
\end{tabular}

DLS measurement. $\zeta$-potential was measured on a Malvern instrument (Zetasizer Nano 90) using the dip-cell setup. In a typical experiment, $\mathrm{TiO}_{2} \mathrm{NPs}$ (final concentration $0.72 \mathrm{nM}$ ) were dispersed in $1 \mathrm{~mL}$ of water or buffer. The typical buffer concentration was $10 \mathrm{mM}$ phosphate, citrate, HEPES, or acetate. The $\mathrm{pH}$ values were adjusted by gradually adding $\mathrm{NaOH}$ or $\mathrm{HCl}$. The temperature was set at $25^{\circ} \mathrm{C}$. DNA adsorption assays. The diameter of our $\mathrm{TiO}_{2} \mathrm{NP}$ is $\sim 20 \mathrm{~nm}$ (supplied by the vendor and also from TEM). Assuming spherical shape and a density of $4.23 \mathrm{~g} / \mathrm{cm}^{3}, 1 \% \mathrm{TiO}_{2}$ has a $\mathrm{NP}$ molar concentration of $940 \mathrm{nM}$. In a typical experiment to measure DNA adsorption kinetics, $1 \mu \mathrm{L}$ of $1 \mu \mathrm{M}$ FAM-labeled DNA (FAM = 6-carboxyfluorescein) stock solution (final concentration $=10 \mathrm{nM}$.) and $2 \mu \mathrm{L}$ of $3 \mathrm{M}$ $\mathrm{NaCl}$ (final concentration $=60 \mathrm{mM}$ ) were mixed in $95 \mu \mathrm{L}$ of HEPES buffer $(5 \mathrm{mM}$, pH 7.6) in a 96- 
well plate. Next, the fluorescence signal baseline (excitation at $485 \mathrm{~nm}$; emission at $535 \mathrm{~nm}$ ) was measured for 1 min under the kinetic mode using a plate reader (Tecan Infinite F200Pro) prior to a quick addition and mixing of $2 \mu \mathrm{L}$ of $45 \mathrm{nM} \mathrm{TiO}{ }_{2}$ NPs (final $\mathrm{TiO}_{2} \mathrm{NP}$ concentration $=0.9 \mathrm{nM}$ ). Afterwards, the fluorescence intensity at $535 \mathrm{~nm}$ was monitored for $45 \mathrm{~min}$ to track the adsorption kinetics. The concentration of $\mathrm{NaCl}$ was varied in the salt-dependent experiments $(\mathrm{NaCl}=0,30,60,90$, $120 \mathrm{mM})$. In the same way, the effect of other anions $\left(\mathrm{NaNO}_{3}, \mathrm{NaOAc}, \mathrm{Na}_{3}\right.$ citrate, and $\left.\mathrm{Na}_{2} \mathrm{HPO}_{4}\right)$ on DNA adsorption was studied. For these assays, the concentration of $\mathrm{Na}^{+}$was maintained constant (60 $\mathrm{mM}$ ), so that the concentration of the anions was different (e.g. [citrate] $\left.=20 \mathrm{mM} ; \mathrm{SO}_{4}{ }^{2-}\right]=30 \mathrm{mM}$ ). For PNA adsorption, the FAM-labeled PNA concentration was $14 \mathrm{nM}$ with $60 \mathrm{mM} \mathrm{NaCl}$.

DNA loading capacity. The loading capacity of DNA was measured by the difference of the fluorescence intensity of each sample before and after addition of $\mathrm{TiO}_{2} \mathrm{NPs}$ for DNA adsorption. The DNA loading under neutral and $\mathrm{pH} 2$ conditions was respectively studied. Under neutral $\mathrm{pH}$, various concentrations of FAM-A $15(0.1,0.2,0.5,1,2 \mu \mathrm{M})$ was mixed with $10 \mathrm{nM} \mathrm{TiO}_{2}$ in $5 \mathrm{mM}$ HEPES buffer ( $\mathrm{pH} 7.6$ with $60 \mathrm{mM} \mathrm{NaCl})$. The total volume was $100 \mu \mathrm{L}$ for each sample $(n=3)$. After overnight incubation under room temperature, the sample solutions were centrifuged and the supernatant fluorescence intensity was measured to quantify adsorbed DNA. For the acidic condition, 2 $\mu \mathrm{L}$ of $0.5 \mathrm{M} \mathrm{HCl}$ solution was added to $90 \mu \mathrm{L}$ Milli-Q water before mixing with a small volume of DNA stock solution $(100 \mu \mathrm{M})$ and $2.7 \mu \mathrm{L} \mathrm{TiO}_{2}$ solution $(360 \mathrm{nM})$ in water at room temperature for 3 min. Afterwards, the mixture was sonicated for $2 \mathrm{~min}$ in a sonication bath prior to a $5 \mathrm{~min}$ centrifugation $(15,000 \mathrm{rpm})$ to precipitate the $\mathrm{TiO}_{2} \mathrm{NPs}$. To monitor the fluorescence intensity of the supernatant, the same volume of $\mathrm{NaOH}(0.01 \mathrm{M})$ was added to $50 \mathrm{mM}$ HEPES buffer to adjust the $\mathrm{pH}$ to neutral. This is important since the FAM fluorescence is a strong function of $\mathrm{pH}$. Care was taken for developing calibration curves, where the same concentration of $\mathrm{Na}^{+}$(using $\mathrm{NaCl}$ ) was added into the standard solution to maintain a consistent ionic strength. 
DNA desorption. To investigate the displacement of adsorbed DNA, the $\mathrm{DNA} / \mathrm{TiO}_{2}$ nanoconjugate was prepared using the $\mathrm{pH} 2$ method to achieve fast and high loading capacity. After three rounds of rinsing with pure water to remove the loosely adsorbed DNA, the conjugate was dispersed in water with the $\mathrm{TiO}_{2}$ concentration being $10 \mathrm{nM}$. Then $5 \mu \mathrm{L}$ of the conjugate was transferred into $90 \mu \mathrm{L}$ of $5 \mathrm{mM}$ HEPES ( $\mathrm{pH}$ 7.6) to measure the fluorescence baseline for $2 \mathrm{~min}$ before a quick addition of $5 \mu \mathrm{L}$ phosphate solution of various concentrations to make the final concentration of phosphate to be $0,0.2$, 2, or $20 \mathrm{mM}$. The fluorescence was monitored for $40 \mathrm{~min}$. The possible displacement of adsorbed DNA by $5 \mathrm{mM}$ nucleosides was also studied (adenosine, guanosine, cytidine, and uridine), where $10 \mu \mathrm{L}$ of nucleosides solution $(50 \mathrm{mM})$ was added to the conjugate solution and incubated for 30 min before measuring the fluorescence intensity.

DNA detection. To study the adsorption kinetics of ss- and ds-DNA, FAM-DNA1 and its cDNA were first hybridized by mixing $10 \mathrm{nM}$ of FAM-DNA1 with various concentrations of cDNA1 or a noncomplementary strand $\left(\mathrm{T}_{15}, 20 \mathrm{nM}\right)$ in $10 \mathrm{mM}$ HEPES (pH 7.6, with $\left.150 \mathrm{mM} \mathrm{NaCl}\right)$. These solutions were heated to $90{ }^{\circ} \mathrm{C}$ and then slowly cooled to room temperature for DNA hybridization. After monitoring background fluorescence for $6 \mathrm{~min}, \mathrm{TiO}_{2} \mathrm{NP}$ (final concentration $=0.9 \mathrm{nM}$ ) was added to each sample and the fluorescence was measured for $1 \mathrm{~h}$.

Fluorescence quenching by $\mathrm{TiO}_{2} \mathrm{NPs}$. To illustrate the fluorescence quenching capability of $\mathrm{TiO}_{2} \mathrm{NPs}_{\text {, }}$ we compared the fluorescence of three samples: (1) free Cy3- $\mathrm{T}_{15}$; (2) Cy3- $\mathrm{T}_{15}$ adsorbed on $\mathrm{TiO}_{2}$; (3) free FAM-T 15 ; (4) FAM-T 15 adsorbed on $\mathrm{TiO}_{2}$. The concentration for DNA concentration was $0.5 \mu \mathrm{M}$ and that for $\mathrm{TiO}_{2}$ NPs was $10 \mathrm{nM}$. The sample (2) and (4) were prepared following the pH 2 procedure described in last section: the ratio of initial concentrations of $\mathrm{DNA} / \mathrm{TiO}_{2} \mathrm{NP}=50$. The conjugates were rinsed twice with pure water to remove the free DNAs and were excited using Safe Imager ${ }^{\text {TM }} 2.0$ Blue Light Transilluminator (Invitrogen). 


\section{Results and Discussion}

Surface properties of $\mathrm{TiO}_{2}$ NPs. The size of our $\mathrm{TiO}_{2}$ NPs is $\sim 20 \mathrm{~nm}$ under TEM (Figure 1A). Since we intend to probe the native surface of $\mathrm{TiO}_{2}$, no capping agent or surfactant was used. When dispersed in water at around neutral $\mathrm{pH}$, the surface charge of $\mathrm{TiO}_{2}$ is close to zero (vide infra). For these reasons, the particles were aggregated. Dynamic light scattering (DLS) shows an average size of $\sim 300 \mathrm{~nm}$, which agrees with aggregation of $\mathrm{TiO}_{2}$ NPs (Figure 1B). More DLS data of the particles in different buffer conditions are shown in Figure S1 of Supporting Information. XRD shows that the particles are crystalline and have the anatase phase (Figure 1C).
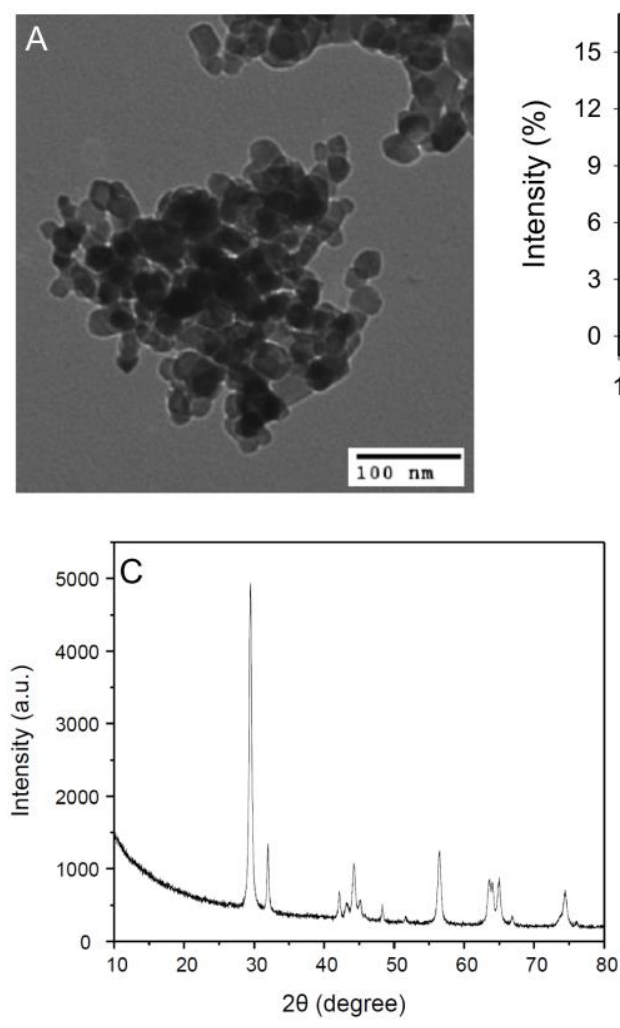

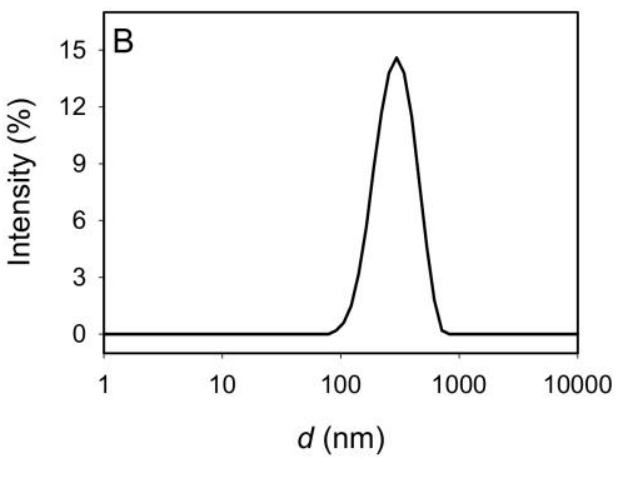

D
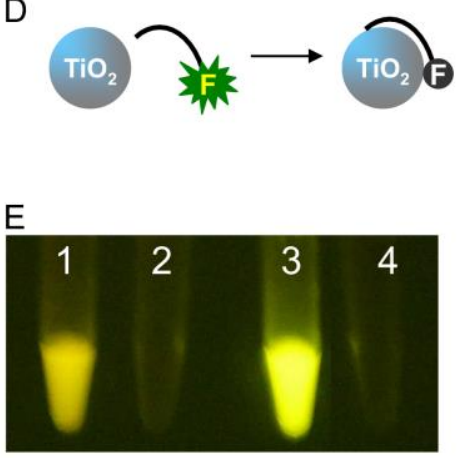

Figure 1. TEM (A), DLS (B) and XRD (C) of the $\mathrm{TiO}_{2} \mathrm{NP}$ samples used in this work. (D) Schematics of fluorescently labeled DNA adsorption by $\mathrm{TiO}_{2} \mathrm{NPs}$ and fluorescence quenching. (E) A fluorescence photograph showing tube 1: free $\mathrm{Cy} 3-\mathrm{T}_{15}$; tube 2: Cy3- $\mathrm{T}_{15}$ adsorbed by $\mathrm{TiO}_{2} \mathrm{NPs}$; tube 3: free FAM$\mathrm{T}_{15}$; tube 4: FAM-T 15 adsorbed by $\mathrm{TiO}_{2}$ NPs. 
Since DNA is a negatively charged polymer, electrostatic interactions are often important for it adsorption. To understand the surface charge of $\mathrm{TiO}_{2} \mathrm{NPs}$, we first measured $\zeta$-potential in water without buffer and adjusted $\mathrm{pH}$ by $\mathrm{HCl}$ or $\mathrm{NaOH}$ (Figure $2 \mathrm{~A}$, black dots). The particles are negatively charged at $\mathrm{pH}$ greater than 7 and positively charged at $\mathrm{pH}$ lower than 6 . This is consistent with literature reports on $\mathrm{TiO}_{2}$ NPs prepared by various methods. ${ }^{31}$ The reactions responsible for its surface charging are shown in the inset of Figure $2 \mathrm{~A} .{ }^{32}$ The data points are quite scattered around neutral $\mathrm{pH}$ since this sample was not buffered. Adding $20 \mathrm{mM}$ acetate buffer has improved the quality of the data and a similar $\mathrm{pH}$-dependent surface charge inversion was also observed (Figure 2A, red dots). To buffer over a wider range of $\mathrm{pH}$, we also measured $\zeta$-potential in phosphate and citrate buffers (Figure 2B), where the surface remained negative in all tested $\mathrm{pH}$ values. It is likely that the $\mathrm{TiO}_{2}$ surface has affinity for the oxygen groups in the phosphate and citrate anions. ${ }^{33}$ Adsorption of these anions rendered negatively charged surface regardless of $\mathrm{pH}$, which might have an adverse effect for DNA adsorption. We performed most of our experiments in $\mathrm{pH}$ 7.6 HEPES and the surface is negatively charged under this condition (blue square, Figure 2B).
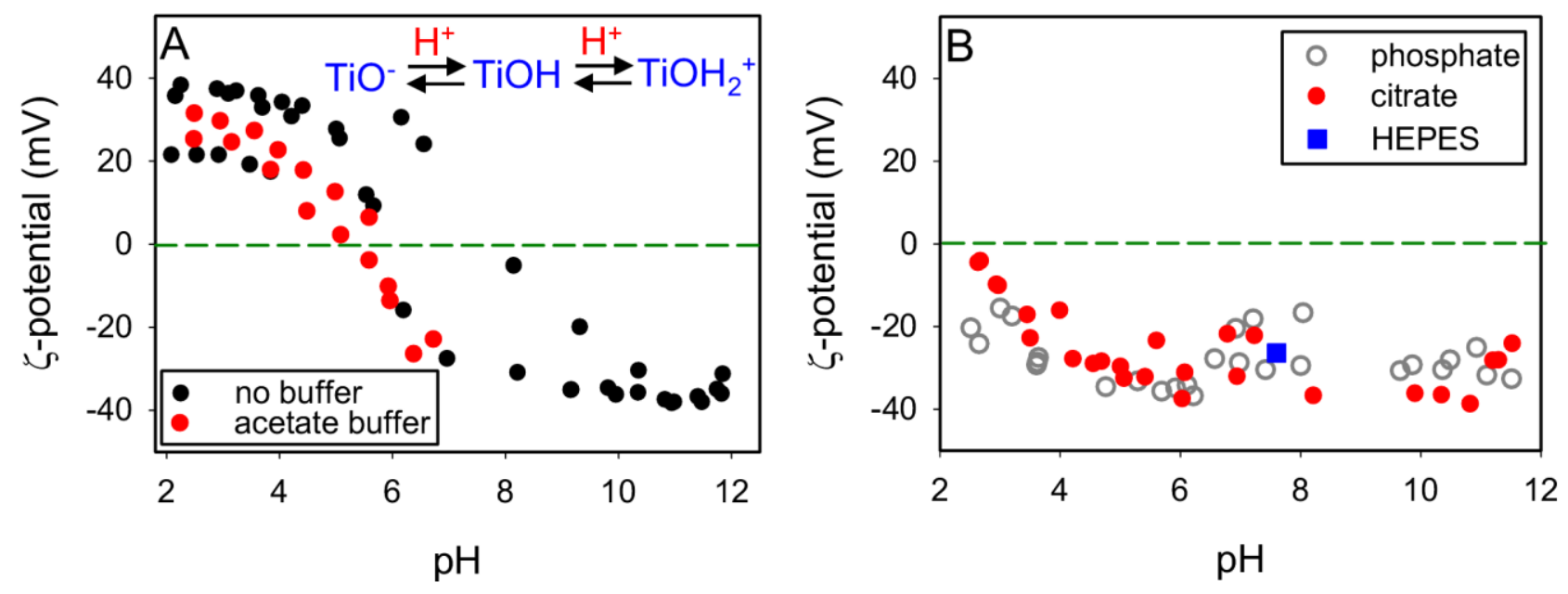

Figure 2. $\zeta$-potential of $\mathrm{TiO}_{2} \mathrm{NP}$ as a function of $\mathrm{pH}$ in water and acetate buffer $(\mathrm{A})$, or in phosphate, citrate, and HEPES buffer. Inset of (A): change of surface charge through protonation for the native $\mathrm{TiO}_{2}$ surface. 
DNA adsorption. After understanding the surface charge of $\mathrm{TiO}_{2} \mathrm{NPs}$, DNA adsorption was studied. First we need to develop an assay to follow DNA adsorption. Since many inorganic surfaces quench adsorbed fluorophores (e.g. carbon nanotubes, ${ }^{34}$ graphene oxide, ${ }^{35,36}$ gold,${ }^{37}$ nanoceria,${ }^{30}$ and quantum $\operatorname{dots}^{38}$ ), we tested whether $\mathrm{TiO}_{2}$ NPs also have such an effect. Figure 1E shows a fluorescence photograph that both FAM and Cy3-labeled DNA are almost fully quenched by $\mathrm{TiO}_{2} \mathrm{NPs}$. This also indicates that DNA oligonucleotides are adsorbed (Figure 1D). $\mathrm{TiO}_{2}$ is a large band-gap semiconductor and might accept electrons from excited fluorophores to quench its fluorescence.

Since phosphate and citrate can be adsorbed by $\mathrm{TiO}_{2} \mathrm{NPs}$ and may cause artifacts for studying DNA adsorption, we chose to use HEPES buffer (pH 7.6) for most of our experiments. The unmodified $\mathrm{TiO}_{2}$ surface carries a negative charge in $\mathrm{pH}$ 7.6 HEPES buffer (Figure 2B). Therefore, to adsorb negatively charged DNA, salt should be important to screen charge repulsion. To test this, we measured FAM-labeled $\mathrm{A}_{15}$ DNA adsorption as a function of $\mathrm{NaCl}$ concentration (Figure 3A). Indeed, little adsorption was observed in the absence of salt and the rate of adsorption was significantly enhanced with more than $30 \mathrm{mM} \mathrm{NaCl}$. Next, we measured the adsorption of 15-mer DNA homopolymers in the presence of $60 \mathrm{mM} \mathrm{NaCl}$ (Figure 3B). These DNAs showed slightly different adsorption behaviors. For example, $A_{15}$ adsorption continued to occur in 90 min while the other three DNA reached a stable fluorescence quite rapidly. The amount of fluorescence quenching (i.e. adsorption) was the least for $\mathrm{G}_{15}$. This might be attributed to DNA secondary structures affecting the adsorption kinetics. For example, poly-G DNA tends to form quadruplex structures, which may hinder adsorption.

Next we tested the effect of DNA length (Figure 3C), where the capacity dropped significantly as the length of DNA increased. This suggests that the DNA wraps around $\mathrm{TiO}_{2} \mathrm{NPs}$ instead of adopting an upright conformation. This capacity is however quite low if we compare it with gold NPs of the same size; each adsorbs $\sim 200$ thiolated DNA with an upright conformation. ${ }^{39}$ Using a random sequenced 12-mer DNA, we measured DNA adsorption capacity as a function of the initial DNA 
concentration (Figure 3D) and our data fit to a Langmuir isotherm. This suggests that there is an adsorption/desorption equilibrium in our system and it is also reasonable that DNA adsorption on $\mathrm{TiO}_{2}$ NP stops at a monolayer. It is quite striking that the capacity becomes much higher when DNA was loaded at $\mathrm{pH} 2$ (Figure 3E). For example, at a $\mathrm{DNA}: \mathrm{TiO}_{2}$ ratio of 100:1, DNA was quantitatively adsorbed for all the tested sequences. Close to complete adsorption was achieved also for $\mathrm{A}_{15}$ and $\mathrm{C}_{15}$ at up to 400:1 ratio, while the capacity was slightly lower for $\mathrm{G}_{15}$ and much lower for $\mathrm{T}_{15}$. On the other hand, at neutral $\mathrm{pH}$, the $\mathrm{A}_{15}$ loading was less than 30 (Figure $3 \mathrm{C}$ ). At $\mathrm{pH} 2$, the $\mathrm{TiO}_{2}$ surface is positively charged and may attract DNA via electrostatic interactions. The negative charges on DNA are from the backbone phosphate, which has a $\mathrm{pK}_{\mathrm{a}}$ value close to 2 . However, protonated phosphate might not bind to the $\mathrm{TiO}_{2}$ surface. We reason that the different capacity at $\mathrm{pH} 2$ is likely due to the different $\mathrm{pK}_{\mathrm{a}}$ values of the bases. $\mathrm{T}_{15}$ cannot be protonated even at $\mathrm{pH} 2$ and thus the thymine base does not contribute electrostatically for $\mathrm{T}_{15}$ DNA adsorption, limiting its capacity to 100 DNA per particle. Guanine has a $\mathrm{pK}_{\mathrm{a}}$ of 2.2 and therefore can be partially protonated at $\mathrm{pH} 2$. The $\mathrm{pK}_{\mathrm{a}}$ values for adenine and cytosine are 3.5 and 4.2, respectively and can be fully protonated at $\mathrm{pH} 2$. This trend matches with our data and thus the ultrahigh capacity of these DNA is related to both protonation of the particle and DNA bases. At pH 2, the loading capacity also decreased with increasing DNA length. Nevertheless, the 30-mer DNA was still loaded at 200 per $\mathrm{TiO}_{2} \mathrm{NP}$ (Figure 3F). Note that each $20 \mathrm{~nm}$ gold NP can only adsorb 180 thiolated 25-mer DNA, where DNA has an upright conformation. ${ }^{39}$ Therefore, to load a similar density of DNA onto $\mathrm{TiO}_{2}$, it is unlikely that each DNA wraps around the particles. More likely, the DNAs are adsorbed via only one or a few nucleotides. Such high DNA loading at low pH is consistent with the report by Suzuki et $a{ }^{23}$ who used long ds-DNA in their study. Here we provide more detailed insight regarding the effect of different DNA sequence, where base protonation appears to be important. Such pH-dependent DNA loading was also observed for gold and silver NPs, ${ }^{26,27,40,41}$ and for graphene oxide. ${ }^{42}$ 

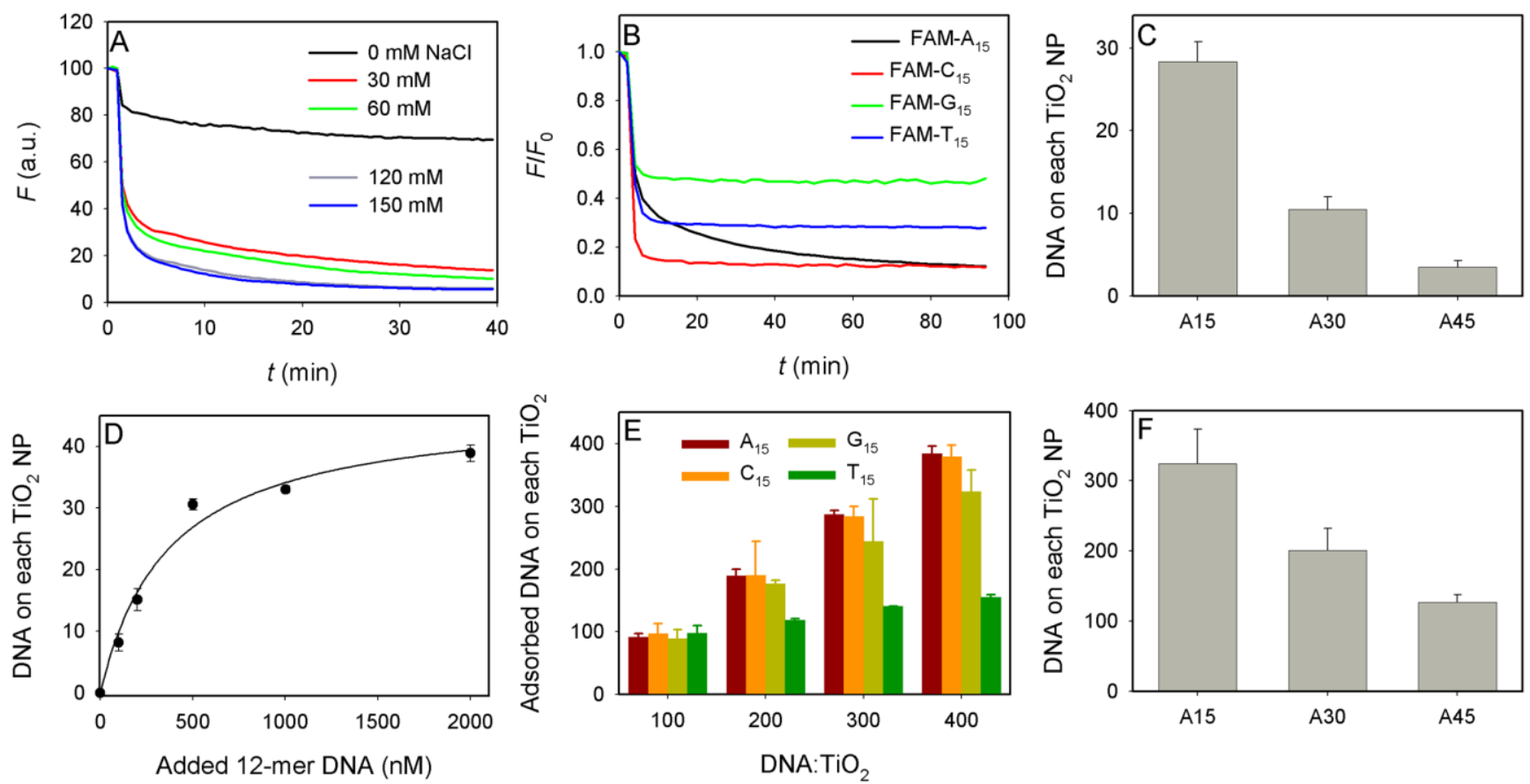

Figure 3. (A) Adsorption of FAM- $\mathrm{A}_{15}$ as a function of $\mathrm{NaCl}$ concentration in $5 \mathrm{mM}$ HEPES buffer. (B) Adsorption kinetics of various DNA sequences. (C) DNA adsorption capacity at $\mathrm{pH} 7.6$ as a function of DNA length. (D) DNA adsorption isotherm at pH 7.6. (E) DNA adsorption capacity at pH 2. (F) DNA adsorption capacity at $\mathrm{pH} 2$ as a function of DNA length.

Desorption and displacement. The above studies were carried out in HEPES buffer. Since $\mathrm{TiO}_{2}$ appears to strongly adsorb phosphate based on our $\zeta$-potential measurement (Figure 2B), we next measured DNA adsorption/desorption in other buffers. An important question is whether DNA adsorption is achieved via the bases or the phosphate backbone. Previous studies have not systematically addressed this question. We herein probed it using displacement reactions. For example, if adsorption is through the backbone phosphate, the adsorbed DNA might be displaced by adding free phosphate. To test this, we loaded the four different DNAs and added various concentrations of phosphate buffer ( $\mathrm{pH}$ 7.4). As shown in Figure 4, all the DNA sequences showed time-dependent fluorescence enhancement and higher concentration of phosphate gave faster signal increase. Therefore, 
DNA phosphate backbone is likely to play an important role in its adsorption. At the same time, the kinetics of FAM-G 15 is the slowest, while all the other three DNAs showed similarly fast desorption. Therefore, it cannot be ruled out that the guanine base might also have some affinity for the $\mathrm{TiO}_{2} \mathrm{NP}$ surface as well. Interestingly, Cleaves et al concluded that the strength of nucleotide adsorption follows the order of $\mathrm{G}>\mathrm{C}>\mathrm{U}>\mathrm{A},{ }^{24}$ which agrees with our data that the poly-G DNA desorbed the slowest. Again, it needs to be emphasized that phosphate adsorption plays the major role. Phosphate induced desorption also indicates that longer DNA is adsorbed slightly more tightly (Figure S2), which is consistent with the lower capacity of the longer DNA (Figure 3F). In other words, lower capacity means more contacting points for each DNA and stronger affinity.
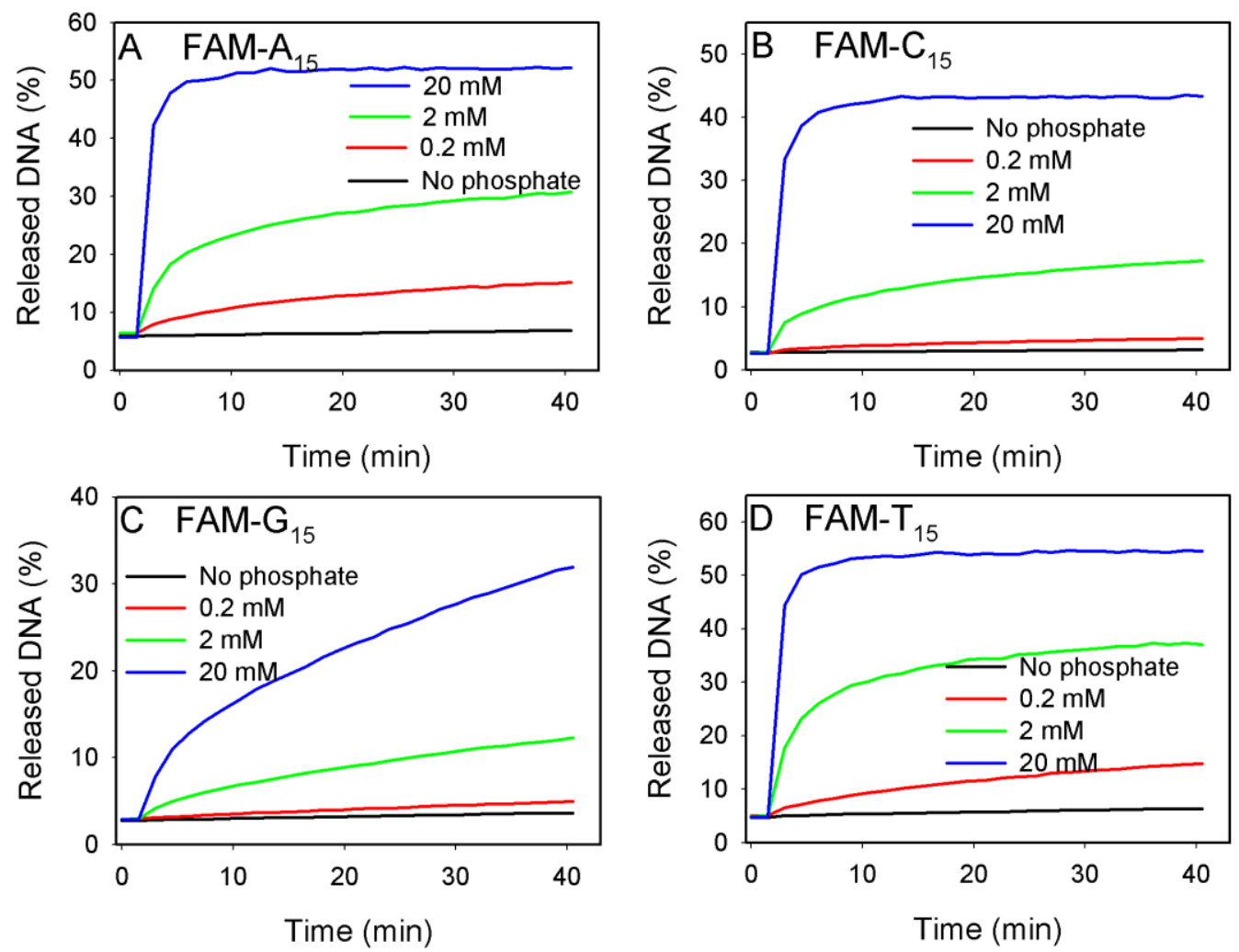

Figure 4. Kinetics of FAM-labeled $\mathrm{A}_{15}(\mathrm{~A}), \mathrm{C}_{15}(\mathrm{~B}), \mathrm{G}_{15}(\mathrm{C})$ and $\mathrm{T}_{15}$ (D) DNA desorption induced by adding various concentrations of phosphate buffer. 
We next used nucleosides for displacement. In this experiment, DNA loaded $\mathrm{TiO}_{2} \mathrm{NPs}_{\text {were }}$ mixed with $5 \mathrm{mM}$ adenosine, cytidine, guanosine or uridine, respectively. After incubation for $30 \mathrm{~min}$, the DNA remained on the particles was quantified (Figure 5A). All the samples showed similar DNA loading as the control without any treatment. Therefore, DNA adsorption should occur mainly via the backbone phosphate instead of the bases. As a further control, a FAM-labeled peptide nucleic acid (PNA) was added and no adsorption was observed (Figure 5B). In a PNA, the amide backbone replaces the phosphate backbone in DNA, while the bases are the same. The lack of PNA adsorption further confirms the phosphate adsorption mechanism; adsorption by the bases in the absence of phosphate was too weak.
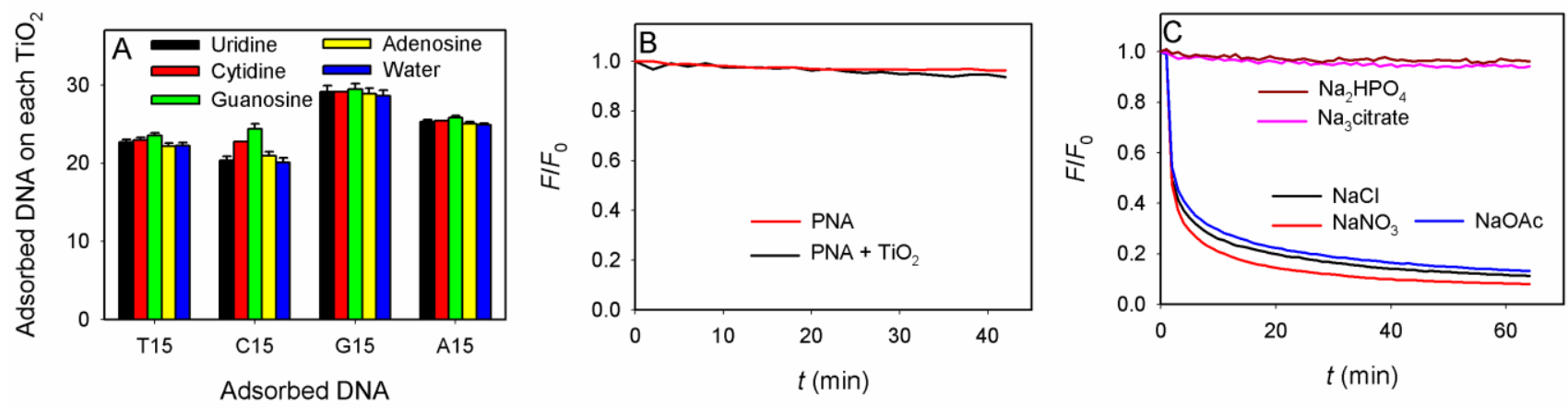

Figure 5. (A) DNA adsorption capacity in the presence of $5 \mathrm{mM}$ various ribonucleosides. The fact that the capacity is similar for all the samples indicates that DNA bases only played a very limited role in contributing DNA adsorption. (B) FAM-labeled PNA does not adsorb on $\mathrm{TiO}_{2}$. (C) FAM-labeled DNA adsorption in buffers containing various salts. $\mathrm{Na}^{+}=60 \mathrm{mM}$ and anion concentration is adjusted accordingly. A large drop in fluorescence indicates effective DNA adsorption.

To have a full understanding of buffer effect, we tested a few other common inorganic anions (20-60 mM concentration). In this case, $\mathrm{TiO}_{2}$ NPs were incubated in buffers containing designated anions and then FAM-A 15 was added (Figure 5C). Phosphate and citrate strongly inhibited DNA 
adsorption, where the fluorescence quenching was less than $10 \%$ in $2 \mathrm{~h}$. Therefore, these anions are likely to cap the nanoparticle surface. On the other hand, nitrate, sulphate and acetate have no inhibition effect. It is interesting that citrate is a strong inhibitor while acetate is not. It is likely that the three carboxyl groups in citrate have strong chelation effect, which is not present in acetate.
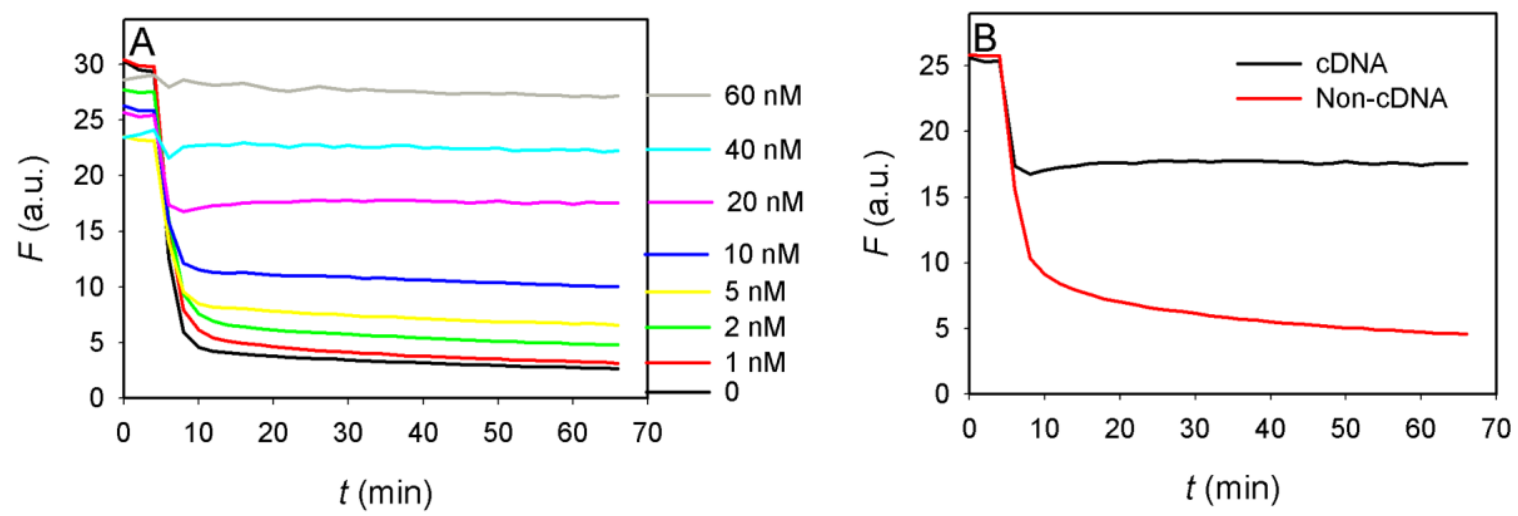

Figure 6. (A) Response of a FAM-labeled probe DNA hybridized with various concentrations of its cDNA after mixing with $\mathrm{TiO}_{2}$ NPs. The higher fluorescence signal with more cDNA indicates that the fluorescence in a ds-DNA is less effectively quenched. (B) For a non-complementary DNA, the response is more similar to that for the free probe DNA, suggesting high specificity. The probe DNA concentration is $10 \mathrm{nM}$, the cDNA concentration in $(\mathrm{B})$ is $20 \mathrm{nM}$. The $\mathrm{TiO}_{2} \mathrm{NP}$ concentration is $0.9 \mathrm{nM}$.

Comparison of ss- and ds-DNA. Combined with fluorescence quenching and DNA adsorption property, we aim to test whether $\mathrm{TiO}_{2}$ NPs can be used for DNA detection. To achieve this, there should be a difference between ss- and ds-DNA. We used a FAM-labeled DNA as probe and hybridized it with various concentrations of cDNA (i.e. the target DNA) to form ds-DNA. The background fluorescence of the hybridized samples was monitored for 5 min before $\mathrm{TiO}_{2}$ NPs were added (Figure 6A). Higher concentration of the cDNA resulted in stronger final fluorescence. Even 1 
nM cDNA gave a response difference from the background, suggesting high sensitivity might be achieved for this assay method. As a control, the suppression of fluorescence was much less effective if a non-target DNA was used (Figure 6B). Since DNA adsorption takes place mainly via the phosphate group and the phosphate backbone is fully exposed in ds-DNA, it is quite surprising that ds-DNA showed less fluorescence quenching. This might be explained by that ss-DNA is much more flexible and the DNA wraps around $\mathrm{TiO}_{2}$ to bring the fluorophore to the particle surface. In a rigid ds-DNA, however, it is more difficult to effectively bend the DNA and some fluorophores might not be effectively quenched. Note in this case adsorption was performed at neutral $\mathrm{pH}$ instead of low $\mathrm{pH}$.

\section{Conclusions}

In summary, we have provided a comprehensive study on $\mathrm{TiO}_{2} \mathrm{NP}$ adsorption of fluorescently labeled DNA oligonucleotides. Care needs to be taken on the surface charge property of $\mathrm{TiO}_{2} \mathrm{NPs}_{\text {, which is }}$ strongly affected by the adsorption of simple inorganic anions: phosphate and citrate cap the surface, making $\mathrm{TiO}_{2}$ NPs negatively charged even at $\mathrm{pH}$ 2. DNA adsorption is achieved mainly via the backbone phosphate while the role of the bases is less important. This is supported by the lack of displacement in the presence of free nucleosides and PNA cannot be adsorbed by $\mathrm{TiO}_{2} \mathrm{NPs}_{\text {. Adsorbed }}$ DNA can be displaced by free phosphate. At the same time, pre-adsorption of phosphate and citrate inhibits DNA adsorption, while nitrate, acetate and chloride have no effect. Both high ionic strength and low $\mathrm{pH}$ promote DNA adsorption and the capacity is drastically increased at $\mathrm{pH} 2$, which is attributed to the DNA base protonation since poly-thymine DNA is less affected. Note that thymine cannot be protonated at $\mathrm{pH}$, while the other three bases can. $\mathrm{TiO}_{2} \mathrm{NP}$ is a strong fluorescence quencher, quenching adsorbed FAM and Cy3 fluorophores. Fluorescence quenching for ds-DNA is much less compared to ss-DNA, which allows sequence specific detection of DNA. 


\section{Acknowledgment}

Funding for this work is from the University of Waterloo, the Canadian Foundation for Innovation, and the Natural Sciences and Engineering Research Council (NSERC) of Canada, the Canadian Institutes of Health Research (CIHR) and the Early Researcher Award from the Ontario Ministry of Research and Innovation.

Supporting Information available. DLS and DNA length dependent desorption. This material is available free of charge via the Internet at http://pubs.acs.org. 


\section{References:}

(1) Adams, L. K.; Lyon, D. Y.; Alvarez, P. J. J. Comparative Eco-Toxicity of Nanoscale $\mathrm{TiO}_{2}, \mathrm{SiO}_{2}$, and $\mathrm{ZnO}$ Water Suspensions. Water Res. 2006, 40, 3527-3532.

(2) Jeng, H. A.; Swanson, J. Toxicity of Metal Oxide Nanoparticles in Mammalian Cells. J. Environ. Sci. Heal. A 2006, 41, 2699-2711.

(3) Newman, M. D.; Stotland, M.; Ellis, J. I. The Safety of Nanosized Particles in Titanium Dioxide- and Zinc Oxide-Based Sunscreens. J. Am. Acad. Dermatol. 2009, 61, 685-692.

(4) Mikkelsen, L.; Sheykhzade, M.; Jensen, K.; Saber, A.; Jacobsen, N.; Vogel, U.; Wallin, H.; Loft, S.; Moller, P. Modest Effect on Plaque Progression and Vasodilatory Function in Atherosclerosis-Prone Mice Exposed to Nanosized $\mathrm{TiO}_{2}$. Part. Fibre Toxicol. 2011, 8, 32.

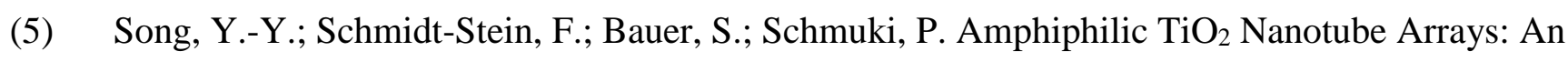
Actively Controllable Drug Delivery System. J. Am. Chem. Soc. 2009, 131, 4230-4232.

(6) Lachheb, H.; Puzenat, E.; Houas, A.; Ksibi, M.; Elaloui, E.; Guillard, C.; Herrmann, J.-M. Photocatalytic Degradation of Various Types of Dyes (Alizarin S, Crocein Orange G, Methyl Red, Congo Red, Methylene Blue) in Water by UV-Irradiated Titania. Appl. Catal. B-Environ. 2002, 39, 75-90.

(7) Ye, L.; Pelton, R.; Brook, M. A.; Filipe, C. D. M.; Wang, H. F.; Brovko, L.; Griffiths, M. Targeted Disinfection of E. Coli Via Bioconjugation to Photoreactive $\mathrm{TiO}_{2}$. Bioconjug. Chem. 2013, $24,448-455$.

(8) Wang, H.; Yang, R. H.; Yang, L.; Tan, W. H. Nucleic Acid Conjugated Nanomaterials for Enhanced Molecular Recognition. ACS Nano 2009, 3, 2451-2460.

(9) Giljohann, D. A.; Seferos, D. S.; Daniel, W. L.; Massich, M. D.; Patel, P. C.; Mirkin, C. A. Gold Nanoparticles for Biology and Medicine. Angew. Chem. Int. Ed. 2010, 49, 3280-3294.

(10) Saha, K.; Agasti, S. S.; Kim, C.; Li, X.; Rotello, V. M. Gold Nanoparticles in Chemical and Biological Sensing. Chem. Rev. 2012, 2739-2779. 
(11) Zhao, W.; Brook, M. A.; Li, Y. Design of Gold Nanoparticle-Based Colorimetric Biosensing Assays. ChemBioChem 2008, 9, 2363-2371.

(12) Liu, J.; Cao, Z.; Lu, Y. Functional Nucleic Acid Sensors. Chem. Rev. 2009, 109, 1948-1998.

(13) Li, D.; Song, S. P.; Fan, C. H. Target-Responsive Structural Switching for Nucleic Acid-Based Sensors. Acc. Chem. Res. 2010, 43, 631-641.

(14) Xu, J.; Zhao, Y. M.; Chen, C. M.; Sun, Y.; Liu, G. Y.; Yan, M. M.; Jiang, Z. Y. Oriented PhotoKilling Tumor Using Antibody-Nano- $\mathrm{TiO}_{2}$ Conjugates and Electroporation Methods. Acta Chimica Sinica 2006, 64, 2296-2300.

(15) Xu, J.; Sun, Y.; Huang, J. J.; Chen, C. M.; Liu, G. Y.; Jiang, Y.; Zhao, Y. M.; Jiang, Z. Y. Photokilling Cancer Cells Using Highly Cell-Specific Antibody- $\mathrm{TiO}_{2}$ Bioconjugates and Electroporation. Bioelectrochemistry 2007, 71, 217-222.

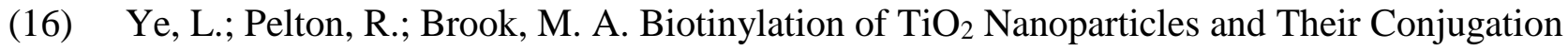
with Streptavidin. Langmuir 2007, 23, 5630-5637.

(17) Ye, L.; Filipe, C. D. M.; Kavoosi, M.; Haynes, C. A.; Pelton, R.; Brook, M. A. Immobilization of $\mathrm{TiO}_{2}$ Nanoparticles onto Paper Modification through Bioconjugation. J. Mater. Chem. 2009, 19, 2189-2198.

(18) Levina, A.; Ismagilov, Z.; Repkova, M.; Shatskaya, N.; Shikina, N.; Tusikov, F.; Zarytova, V. Nanocomposites Consisting of Titanium Dioxide Nanoparticles and Oligonucleotides. $J$. Nanosci. Nanotechno. 2012, 12, 1812-1820.

(19) Levina, A. S.; Repkova, M. N.; Ismagilov, Z. R.; Shikina, N. V.; Malygin, E. G.; Mazurkova, N. A.; Zinov'ev, V. V.; Evdokimov, A. A.; Baiborodin, S. I.; Zarytova, V. F. High-Performance Method for Specific Effect on Nucleic Acids in Cells Using TiO 2 DNA Nanocomposites. Sci. Rep. 2012, 2.

(20) Zhu, R.-R.; Wang, S.-L.; Zhang, R.; Sun, X.-Y.; Yao, S.-D. A Novel Toxicological Evaluation of $\mathrm{TiO}_{2}$ Nanoparticles on DNA Structure. Chin. J. Chem. 2007, 25, 958-961. 
(21) Suzuki, H.; Amano, T.; Toyooka, T.; Ibuki, Y. Preparation of DNA-Adsorbed $\mathrm{TiO}_{2}$ Particles with High Performance for Purification of Chemical Pollutants. Environ. Sci. Technol. 2008, 42, 8076-8082.

(22) Toyooka, T.; Amano, T.; Suzuki, H.; Ibuki, Y. DNA Can Sediment $\mathrm{TiO}_{2}$ Particles and Decrease the Uptake Potential by Mammalian Cells. Sci. Total Environ. 2009, 407, 2143-2150.

(23) Amano, T.; Toyooka, T.; Ibuki, Y. Preparation of DNA-Adsorbed $\mathrm{TiO}_{2}$ Particles Augmentation of Performance for Environmental Purification by Increasing DNA Adsorption by External pH Regulation. Sci. Total Environ. 2010, 408, 480-485.

(24) Cleaves, H. J.; Jonsson, C. M.; Jonsson, C. L.; Sverjensky, D. A.; Hazen, R. M. Adsorption of Nucleic Acid Components on Rutile $\left(\mathrm{TiO}_{2}\right)$ Surfaces. Astrobiology 2010, 10, 311-323.

(25) Rosi, N. L.; Mirkin, C. A. Nanostructures in Biodiagnostics. Chem. Rev. 2005, 105, 1547-1562.

(26) Zhang, X.; Liu, B.; Dave, N.; Servos, M. R.; Liu, J. Instantaneous Attachment of an Ultrahigh Density of Nonthiolated DNA to Gold Nanoparticles and Its Applications. Langmuir 2012, 28, 17053-17060.

(27) Zhang, X.; Servos, M. R.; Liu, J. Surface Science of DNA Adsorption onto Citrate-Capped Gold Nanoparticles. Langmuir 2012, 28, 3896-3902.

(28) Wu, M.; Kempaiah, R.; Huang, P.-J. J.; Maheshwari, V.; Liu, J. Adsorption and Desorption of DNA on Graphene Oxide Studied by Fluorescently Labeled Oligonucleotides. Langmuir 2011, 27, 2731-2738.

(29) Wang, F.; Liu, B.; Huang, P.-J. J.; Liu, J. Rationally Designed Nucleobase and Nucleotide Coordinated Nanoparticles for Selective DNA Adsorption and Detection. Anal. Chem. 2013, 85, 12144-12151.

(30) Pautler, R.; Kelly, E. Y.; Huang, P.-J. J.; Cao, J.; Liu, B.; Liu, J. Attaching DNA to Nanoceria: Regulating Oxidase Activity and Fluorescence Quenching. ACS Appl. Mater. Inter. 2013, 5, $6820-6825$. 
(31) Liao, D. L.; Wu, G. S.; Liao, B. Q. Zeta Potential of Shape-Controlled $\mathrm{TiO}_{2}$ Nanoparticles with Surfactants. Colloid. Surface. A. 2009, 348, 270-275.

(32) Xu, G.; Zhang, J.; Li, G.; Song, G. Effect of Complexation on the Zeta Potential of Titanium Dioxide Dispersions. J. Disper. Sci. Technol. 2003, 24, 527-535.

(33) Nelson, B. P.; Candal, R.; Corn, R. M.; Anderson, M. A. Control of Surface and $\zeta$ Potentials on Nanoporous $\mathrm{TiO}_{2}$ Films by Potential-Determining and Specifically Adsorbed Ions. Langmuir 2000, 16, 6094-6101.

(34) Yang, R. H.; Jin, J. Y.; Chen, Y.; Shao, N.; Kang, H. Z.; Xiao, Z.; Tang, Z. W.; Wu, Y. R.; Zhu, Z.; Tan, W. H. Carbon Nanotube-Quenched Fluorescent Oligonucleotides: Probes That Fluoresce Upon Hybridization. J. Am. Chem. Soc. 2008, 130, 8351-8358.

(35) Lu, C. H.; Yang, H. H.; Zhu, C. L.; Chen, X.; Chen, G. N. A Graphene Platform for Sensing Biomolecules. Angew. Chem. Int. Ed. 2009, 48, 4785-4787.

(36) Huang, P.-J. J.; Liu, J. DNA-Length-Dependent Fluorescence Signaling on Graphene Oxide Surface. Small 2012, 8, 977-983.

(37) Dubertret, B.; Calame, M.; Libchaber, A. J. Single-Mismatch Detection Using Gold-Quenched Fluorescent Oligonucleotides. Nat. Biotechnol. 2001, 19, 365-370.

(38) Lu, W. B.; Qin, X. Y.; Luo, Y. L.; Chang, G. H.; Sun, X. P. CdS Quantum Dots as a Fluorescent Sensing Platform for Nucleic Acid Detection. Microchimica Acta 2011, 175, 355359.

(39) Hill, H. D.; Millstone, J. E.; Banholzer, M. J.; Mirkin, C. A. The Role Radius of Curvature Plays in Thiolated Oligonucleotide Loading on Gold Nanoparticles. ACS Nano 2009, 3, 418424.

(40) Zhang, X.; Liu, B.; Servos, M. R.; Liu, J. Polarity Control for Nonthiolated DNA Adsorption onto Gold Nanoparticles. Langmuir 2013. 
(41) Zhang, X.; Servos, M. R.; Liu, J. Instantaneous and Quantitative Functionalization of Gold Nanoparticles with Thiolated DNA Using a pH-Assisted and Surfactant-Free Route. J. Am. Chem. Soc. 2012, 134, 7266-7269.

(42) Huang, P.-J. J.; Kempaiah, R.; Liu, J. Synergistic pH Effect for Reversible Shuttling AptamerBased Biosensors between Graphene Oxide and Target Molecules. J. Mater. Chem. 2011, 21, 8991-8993. 